\title{
Teaching Practice, a Challenge to Teacher Education Program in Indonesia
}

\author{
Faridah \\ Faculty of Educational Science \\ Universitas Negeri Makassar \\ Makassar, Indonesia \\ faridah@unm ac.id \\ Arismunandar \\ Faculty of Educational Science \\ Universitas Negeri Makassar \\ Makassar, Indonesia \\ arismunandar@unm.ac.id
}

\author{
Bernard \\ Faculty of Mathematics and Natural Science \\ Universitas Negeri Makassar \\ Makassar, Indonesia \\ Email: nard_unm@yahoo.com
}

\begin{abstract}
This papers focuses on Teaching Practice component, one of the critical elements in teacher education program in Universitas Negeri Makassar (UNM), South Sulawesi, Indonesia. It discusses how the concept of Teaching Practice is perceived and understood by mentor teacher (Guru Pamong). It also explores how this perception has shaped the role of mentor teacher and prospective teachers' activities during their Teaching Practice program in teacher training schools. Qualitative approach is used in this study. Interviews were conducted to mentor teachers at primary and junior secondary training school. The findings show that mentor teachers have received less preparation to conduct their role as a mentor. The way they do their work, highly depend on their perception about the purpose of Teaching Practice, and their previous experiences as mentor teachers. Hence, each prospective teachers might experience different program or activities depending on their creativity and the demand of their mentor teachers.
\end{abstract}

Keywords- Teaching Practice, teacher education, Guru Pamong, mentor teacher, Indonesia

\section{INTRODUCTION}

Teacher education program in Indonesia has received greater attention since the issue of Techer Law (UndangUndang Guru dan Dosen) in 2005. Many education practitioners see this as critical stage to improve teacher quality through teacher education program. New teacher competences are introduced, namely: pedagogic, personal, social and professional competences. This Law admits teaching as a professional work, where teachers are required to be certified as a professional teacher. It also explains about teacher qualification and teacher certification program [1]. This law about teacher qualification is crucial since there are still teacher who do not hold Bachelor Degree, particularly for primary school teachers [2].

Following the Teacher Law, the Government issues National Standard of Teachers' Academic Qualifications and Teachers' Competences in 2007. Overall, there are 24 teacher's competences required for teachers [3].. For in-service teachers, to be certified as professional teachers, they are required to take teacher certification program named Pendidikan dan Latihan Profesi Guru, PLPG, (Professional Teacher Education and Training).

In 2009, the National Government issued a regulation on pre-service Professional Teacher Education Program. The Government introduced new program called Pendidikan Profesi Guru (PPG), Teacher Professional Education. According to Law on Education No. 20/2003 about National Education System, professional education is a higher education after Bachelor program that prepare participants to have special skills required for works [4]. Hence, it can be said that Teacher Professional Education Program is organized for graduates of Bachelor Program who interest to become teachers.

The purpose of this Professional Education is to produce prospective teachers who have competencies in planning, are competent in planning, implementing and assessing learning, and following up on assessment results [5] In addition, these prospective teachers are also expected to be competent in conducting research, and developing professionalism on an ongoing basis.

Teacher education has been constructed as part of the policy problem [6]. The quality of teachers, the quality of education has always been measured based on certain standards according to the policy that is constantly changing. The emergence and changing policy on education and teacher education have shown us how these issues have become major concern from the Government of Indonesia to improve the quality of education in the country. 
Teaching Practice is one of important component in teacher education program. In Indonesia, the component of Teaching Practice occurs in both Bachelor of Education program and Teacher Professional Program. This Teaching Practice is called PPL (Praktik Pengalaman Lapangan). The purpose of Teaching Practice is to provide participants to have real and contextual experiences in applying a set of knowledge, attitudes, and skills that can support the achievement of the four teachers' competences [5].

At UNM, the implementation of Teaching Practice for Bachelor of Education is usually on semester 7 and known as PPL 1 and PPL 2. PPL 1 is implemented on campus in the form of micro teaching, and PPL 2 is implemented in schools for about three months. Recently, higher education institutions in Indonesia are required to fit their curriculum with National Qualification Framework (KKNI). Referring to this KKNI, Teaching Practice is conducted to provide early learning experiences through a tiered internship. The activities of Teaching Practice consists of field observation, Teaching Practice, personal and social competence development, and non-teaching activities [5].

Study on teacher education is recommended to be done by seeing the interrelationship between policy, local community context, and the practice of teacher education program [7]. This study aims at exploring how Teaching Practice is implemented as part of teacher education program at UNM. It is expected that this study could fill the gap between theory and practice about teacher education program. The results of the study could be uses as a basis for the future development of teacher education program in Indonesia, especially the component of Teaching Practice.

\section{METHOD}

This study used qualitative approach. It was conducted at three schools, primary, secondary, and vocational school. This study does not aim at doing generalization, it focuses more on understanding a case [8], the component of Teaching Practice in teacher education program. Participants in the study consists of school principals, mentor teacher, university students who have done Teaching Practice, and the head of Teaching Practice Unit from the University.

The data collection is done through interview, focus group discussion (FGD), and documentary sources. FGD could help to obtain information that is sometimes difficult to get from individual interview [9]. Interview is conducted to the Head of Teaching Practice at UNM. FGD is done at schools which was attended by school principals, and three mentor teachers. For students, 10 students from different study programs were invited to join the discussion.

The FGD was led by the researcher. We acknowledged that the position as a researcher and academic staff would bring the impression of superiority to the participants [9]. Therefore, the FGD began with an introduction about the study and its purposes. During the discussion, appreciations were shown to participants' views and responses. The data collected were analysed based on the issues emerged during the discussion [10].
Documentary sources used in this study were Teaching Practice Guidelines published by the University, instruments for assessment, product of the Teaching Practice, and time schedule activities at schools. These documents were analysed and interpreted as the reality of Teaching Practice [11].

\section{RESULTS AND DISCUSSIONS}

Our first reflection came from the students who had already done Teaching Practice component during their undergraduate studies. They said that sometimes they were unsure about what they need to do at school during their Teaching Practice stage. What they understood was, Teaching Practice was about being at school and did some teaching. Lack of feedback, unclear programs, are some of the issues they encountered in their Teaching Practice. A series of activities at school highly depend on their own creativity, and support from their mentor teachers.

\section{A. What is Teaching Practice?}

First research question that we tried to examine was how Teaching Practice was understood and perceived by schools. The findings show that Teaching Practice for mentor teachers and students is about coming to school and teach. Because of this perception, other tasks/activities that are not related to teaching directly, seem to be ignored or do not become part of Teaching Practice component. Tasks that can facilitate the development of personal and social competences, field observation, and other non-teaching activities (e.g. school management and administrative work), are not taken seriously as part of Teaching Practice activities at school. This research argues this perception has led to misconception that being a teacher is only about teaching specific topic / subject. When student teachers are expected to be achieve the four teacher competencies, professional, pedagogic, personality, and social, then, Teaching Practice component should be understood as a stage of learning that allow student teachers to explore these competencies.

School principals that involved in this study revealed that they rarely interacted with student teachers who were doing their Teaching Practice. Most of the activities were handled by mentor teacher, and focused more on teaching preparation. They admitted that non-teaching activities we usually done by involving student teachers in extracurricular activities, administrative work, or helping in library. Yet, these nonteaching activities become complementary only, because the focus was on teaching in the classroom.

Documentary analysis also shows that assessment on Teaching Practice stage strongly focuses on teaching aspects. Student teachers are assessed based on their lesson plan, media and teaching strategy they used, and how they conducted classroom assessment. It is not clear what and how they are evaluated when they involved in non-teaching activities at school as part of their learning process to become a teacher.

\section{B. Issues on partnership between schools and university}

Issues on equal partnership emerged during the discussion. According to school principals and mentor teachers, they have limited opportunities to involve and communicate openly with universities regarding Teaching Practice activities. The lack of 
clarity of the roles and responsibilities of school and University as a partner in teacher education program makes student teachers have to clarify themselves about the purpose of Teaching Practice that they do. This situation could lead to frustration for student teachers in their Teaching Practice [12].

In the guide book about Teaching Practice, it is stated that program and activities in Teaching Practice stage is implemented in the form of limited training, guided training, and self-directed training [13]. Research findings show that the lack of communication between school and university has made mentor teacher do their work as mentor based on the guide book only. They also refer to previous Teaching Practice that was done by student teachers in the past. As a result, how to conduct Teaching Practice activities in school is mostly based on the understanding of the guide book and mentor teachers' experiences as mentor. Mentor teachers do not know what has been taught in campus, on the other hand university is also not well informed about good practice in teaching in school [14]. Both student teacher and mentor teachers acknowledged that learnings are not maximal during the Teaching Practice.

Some student informants also mentioned about the schools where they did their Teaching Practice. They said sometimes schools were not ready enough to receive students for their Teaching Practice. The prospective teachers recommended that it was important for university to have certain criteria about teacher training school that is going to be partner in Teaching Practice. They believed if university selected schools carefully following certain criteria, this would allow them to learn more from schools during their Teaching Practice.

Zeichner (2011) writes that democratic and inclusive partnership are needed between university, schools and community in order to achieve the mission of teacher education. He explains that one of the most challenging task he found is to mobilize the thinking on how to strengthen the linkage between teacher education program and what are done by prospective teachers at school when they are doing their practicum. He argues that even though many of supervisor teach and supervise teacher candidates very well, but most of them are not interested in teacher education as a specific field of study. They might be experts in teaching reading or mathematics, but they are not aware of research findings on how to support teacher candidates and make connections to what they have learned in university [14].

Studies conducted by UPT PPL UNM (2016) found that teacher candidates felt they had limited guidance from university mentors [16]. They said that mentor teachers from schools had helped them more during their Teaching Practice. While mentor from university had very limited time to observe and supervise them. This could happen because mentor teacher had more times than university mentors. Interview with the Head of UPT PPL UNM revealed that the preparation for Teaching Practice has not implemented optimally. Time, financial support, commitment, were some of the factors he mentioned. Zeichner (2011) explains about the lack of incentives given to mentors which impact the way they invest their time as mentors [14].
Ways to integrate knowledge and practice is essential to do if we want to help teachers to develop the resources they have for work [15]. The component of Teaching Practice is one of the strategic component to integrate between theory and practice in teaching, and how to become a teacher. For the campus, the experience of teacher candidates during their Teaching Practice program could be considered as valuable input to teacher education curriculum.

\section{Evaluation and The strategic Role of Teaching Practice in Teacher Education Program}

Darling Hammond writes about the impact of teacher education program to the quality of teachers [16]. Although many people believe that everybody could teach, but studies showed that teachers who were trained and certified are found to be better in doing their job than those who were not trained. Hence, it is important for university to provide opportunity for prospective teacher to learn through their experiences during their Teaching Practice stage.

According to Zeichner (2011) prospective teachers have limited opportunities to do observation, trials, and receiving feedback about teaching methods from experienced mentors. The findings showed that during their Teaching Practice, these prospective teachers has chances to have real experiences in teaching classroom [14]. Yet, how these experiences led to learning process with powerful feedback is still unclear. Some mentor teachers said that many of the prospective teachers came to school, ask for teaching documents (e.g. teaching materials, lesson plan), took it, used it as examples, and then left the school, without any questions and discussion with them. The next day, they came back to school to teach. Mentor teachers also explained that although school observation was conducted by prospective teachers, they had rarely had a chance to discuss about it. Mentor teachers also mentioned about the evaluation sheet provided by university. In their opinion, the evaluation sheet did not represent the progress of each prospective teacher. Rather, it was used as summative evaluation only.

Helping teachers to use the resources they have for teaching, it is essential to find a way to integrate between theoretical and practical knowledge [15]. Teaching Practice component can be seen as strategic course where prospective teachers have the opportunities to link between what they have learned in university and what they experience in schools. For university who administer teacher education program, Teaching Practice component can be used as part of the evaluation tools to see how the curriculum of teacher education link with the actual context of schools. It also gives information about the readiness of prospective teachers when they go to school to do their practicum in the real school context.

\section{CONCLUSION}

The results showed that the perception about Teaching Practice had influenced the way Teaching Practice were at school level. The main perception is that prospective teachers come to school to teach only. As a result, the component of school observation and other non-teaching activities are seen as complementary activities only. 
This study also reveals that prospective teachers have less understanding about what they actually need to do during their Teaching Practice. Limited guidance from university mentor, lack of communication between schools and universities, are some factors that affect the implementation of Teaching Practice, one of the critical element of teacher education program at UNM. Issue on financial aspect is also identified as important factor that influence how university mentors invest their time at schools during Teaching Practice.

This study recommends for further action where schools and university work together to identify their role and responsibilities.

\section{ACKNOWLEDGMENT}

We would like to thank Universitas Negeri Makassar for providing research grant to conduct this study. We also thank all participants for their participation and cooperation during the data collection. Hopefully, this study will be beneficial for the future development of teacher education program at UNM in particular.

\section{REFERENCES}

[1] President of the Republic of Indonesia.(2005). Undang-Undang Guru dan Dosen (Teachers and Educators Act) (UU No. 14/2005). Jakarta: Pemerintah Republik Indonesia.

[2] Raihani, \& Sumintono, B. (2010). Teacher education in Indonesia: Development and challenges. In K. G. Karras \& C. C. Wolhuter (Eds.), International handbook of teahcer education world-wide: Issues and challenges (pp. 181-197). Athens: Atrapos Editions.

[3] Ministry of National Education. (2007). Sertifikasi bagi guru dalam jabatan (In-service teacher certification) (Permendiknas No. 18/2007). Jakarta: Pemerintah Republik Indonesia.

[4] President of the Republic of Indonesia. (2003). Undang-Undang RI tentang Sistem Pendidikan Nasional (Law on National Educational System) (UU No. 20/2003). Jakarta: Pemeritah Republik Indonesia.
[5] Direktorat Pembelajaran. (2016). Panduan Pendidikan Profesi Guru. Jakarta: Direktorat Jenderal Pembelajaran dan Kemahasiswaan, Kementerian Riset, Teknologi, dan Pendidikan Tinggi.

[6] Cochran-Smith, M. (2005). The new teacher education: For better or for worse? Educational Researcher, 34(7), 3-17.

[7] Grossman, P., \& McDonald, M. (2008). Back to the future: Directions for research in teaching and teacher education. American Educational Research Journal, 45(1), 184-205.M. Young, The Technical Writer's Handbook. Mill Valley, CA: University Science, 1989.

[8] Stark, S., \& Torrance, H. (2005). Case study. In B. Somekh \& C. Lewin (Eds.), Research methods in the social sciences (pp. 33-40). London: SAGE Publications Ltd.

[9] Barbour, R. S., \& Schostak, J. (2005). Interviewing and focus groups. In B. Somekh \& C. Lewin (Eds.), Research methods in the social sciences (pp. 41-48). London: Sage Publications Ltd.

[10] Perakyla, A., \& Ruusuvuori, J. (2011). Analyzing talk and text. In N. K. Denzin \& Y. S. Lincoln (Eds.), The SAGE handbook of qualitative research. (pp. 529-544). Thousand Oaks, CA: SAGE Publications, Inc.

[11] Gidley, B. (2004). Doing historical and archival research. In C. Seale (Ed.), Researching society and culture (2nd ed., pp. 250-264). Los Angeles: Sage Publications.

[12] Jeanne Maree Allen \& Suzie Elizabeth Wright (2014) Integrating theory and practice in the pre-service teacher education practicum, Teachers and Teaching: theory and practice, 20:2, 136-151, DOI: 10.1080/13540602.2013.848568

[13] UPT PPL UNM. (2016). Panduan Pelaksanaan Praktik Pengalaman Lapangan UNM. Makassar.

[14] Zeichner, K. (2011). Rethinking the connection between campus courses and field experiences in College - and University-based teacher education. Journal of Teacher Education, 61(1-2), 89-99.

[15] Ball, D. L. (2000). Bridging practices: Intertwining content and pedagogy in teaching and learning to teach. Journal of Teacher Education, 51(3), 241-247

[16] Darling-Hammond, L. (2000). How teacher education matters. Journal of Teacher Education, 51(3), 166-173.

[17] Ministry of National Education. (2009). Program Pendidikan Profesi Guru Pra Jabatan (Pre-Service Professional Teacher Education Program) (Permendiknas No. 8/2009). Jakarta: Pemerintah Republik Indonesia. 